\title{
LOSS OF MUSCARINIC RECEPTORS AND OF STIMULATED PHOSPHOLIPID LABELING IN IBOTENATE-TREATED HIPPOCAMPUS ${ }^{1}$
}

\author{
STEPHEN K. FISHER, KIRK A. FREY, AND BERNARD W. AGRANOFF ${ }^{2}$
}

Neuroscience Laboratory and Department of Biological Chemistry, The University of Michigan, Ann Arbor, Michigan 48109

\begin{abstract}
The stimulation of phospholipid labeling by muscarinic agonists has been examined in nerve ending preparations from lesioned hippocampus in order to investigate the synaptic locus of the effect. Unilateral injections of the neurotoxin, ibotenic acid, into the hippocampus resulted in an extensive loss of nerve cells from both the dentate gyrus and hippocampus on the lesioned side and a parallel loss of muscarinic receptors as revealed by $\left[{ }^{3} \mathrm{H}\right]$ quinuclidinyl benzilate autoradiography. Homogenates and nerve ending fractions prepared from the lesioned side of the hippocampus possessed a reduced specific activity (expressed per milligram of protein) of glutamic acid decarboxylase as well as a reduced number of muscarinic receptors compared with the control side. By contrast, choline acetyltransferase activity was either unchanged or slightly increased on the lesioned side. Although there was a reduced yield $(25 \%)$ of nerve endings from the lesioned side, the specific activity of ${ }^{32} \mathrm{P}_{\mathrm{i}}$ incorporation into phospholipids in the absence of added carbachol was comparable to that of the control side. There was, however, a marked reduction in the carbachol stimulation of phosphatidic acid and phosphatidylinositol labeling in nerve ending fractions obtained from the lesioned hippocampus. These results indicate that the muscarinic receptors present in nerve ending fractions from hippocampus and implicated in stimulated phospholipid turnover are derived from cholinoceptive intrinsic neurons.
\end{abstract}

The occurrence, regional distribution, and binding characteristics of muscarinic receptors in the central nervous system have been investigated intensively in recent years (for reviews, see Birdsall and Hulme, 1976; Ehlert et al., 1981). Little information exists, however, concerning the biochemical consequences of the ligandreceptor interaction. One relevant observation is the stimulation of labeling from ${ }^{32} \mathrm{P}_{\mathrm{i}}$ of two quantitatively minor phospholipids, phosphatidic acid (PhA) and phosphatidylinositol ( $\mathrm{PhI})$, that is observed on the addition of muscarinic agonists to slices or minces of cerebral cortex (Hokin and Hokin, 1955; Reddy and Sastry, 1979), caudate nucleus (Canessa de Scarnati et al., 1976), and intact sympathetic ganglia (Hokin, 1966; Lapetina et al., 1976) or to isolated nerve ending preparations from the central nervous system (Schacht and Agranoff, 1972; Yagihara and Hawthorne, 1972; Fisher et al., 1980). This

\footnotetext{
' This work was supported by National Institutes of Health Grant NS 15413. S. K. F. was supported by National Institute of Mental Health Training Grant MH 15794-01. K. A. F. was a trainee under National Institutes of Health Grant 1 T32 GM07863.

${ }^{2}$ To whom correspondence should be addressed at Neuroscience Laboratory Building, The University of Michigan, 1103 E. Huron, Ann Arbor, MI 48109.
}

increase in the labeling of $\mathrm{PhA}$ and $\mathrm{PhI}$ likely reflects an exchange-resynthesis of these lipids, the initial event being the receptor-mediated breakdown of a phosphoinositide (PhI or phosphatidylinositol phosphate or diphosphate) to yield diglyceride, which, in turn, is converted to $\mathrm{PhA}$ and $\mathrm{PhI}$ (for review, see Hawthorne and Pickard, 1979).

The functional significance of the enhanced turnover of $\mathrm{PhA}$ and $\mathrm{PhI}$ is not yet understood, although some speculation over its possible relevance to transmembrane signaling has been made (Hawthorne and Pickard, 1979). A factor which has hindered progress in the understanding of this effect is that the receptor-mediated alterations of phospholipid turnover require cell integrity and, in general, cannot be observed in broken cell preparations. An exception to this is the increase in PhA and $\mathrm{PhI}$ turnover observed in nerve ending fractions on the addition of muscarinic agonists. Nerve endings can be considered to be resealed vesicles in which the vectorial properties of the neuron are preserved, and thus, the preparation offers a relatively simple system in which molecular events underlying synaptic action may be studied. Since muscarinic receptors may be present on both cholinergic and non-cholinergic nerve endings (Szerb and Somogyi, 1973; Giorguieff et al., 1977; Hery et al., 1977; 
deBelleroche and Bradford, 1978), it is uncertain which structures in the nerve ending preparation are responsible for the effect. In a previous study, we observed that prior destruction of the sole cholinergic input to the hippocampus neither reduced the number of muscarinic receptors in nerve ending fractions derived from the hippocampus nor altered the magnitude of muscarinic stimulation of PhA and PhI labeling (Fisher et al., 1980). This result suggested that the muscarinic receptors coupled to enhanced phospholipid turnover were located on cholinoceptive rather than cholinergic structures. In this study, we have used the neurotoxin, ibotenic acid, to test this hypothesis. Intracerebral injections of ibotenate result in a selective destruction of neuronal cell bodies, while presynaptic terminals and axons of passage derived from extrinsic neurons remain unaffected (Kohler et al., 1979; Schwarcz et al., 1979). This agent thus permits an evaluation of the effects of destruction of hippocampal intrinsic neurons on muscarinic receptor content and on stimulated phospholipid labeling.

\section{Materials and Methods}

${ }^{32} \mathrm{P}_{\mathrm{i}}$ (carrier free), $\left[{ }^{14} \mathrm{C}\right]$ acetylcoenzyme $\mathrm{A}(56.6 \mathrm{mCi} /$ $\mathrm{mmol})$, and $\mathrm{L}-\left[1-{ }^{14} \mathrm{C}\right]$ glutamic acid $(50 \mathrm{mCi} / \mathrm{mmol})$ were obtained from Amersham, Arlington Heights, IL. L$\left[{ }^{3} \mathrm{H}\right]$ Quinuclidinyl benzilate (QNB; $\left.40.2 \mathrm{Ci} / \mathrm{mmol}\right)$ was purchased from New England Nuclear, Boston, MA. Carbamylcholine, muscarine, acetylcholine, eserine, arecoline, oxotremorine, bethanechol, pilocarpine, methacholine, and $d$-tubocurarine were obtained from Sigma Chemical Co., St. Louis, MO. Unlabeled QNB was the generous gift of Dr. Charlotte Otto (University of Michigan, Dearborn, MI). Ibotenic acid was obtained from the Regis Chemical Co., Morton Grove, IL.

Ibotenic acid lesions of the hippocampus. Thirty-four male guinea pigs (330 to $500 \mathrm{gm})$ were anesthetized with diethyl ether and placed in a stereotaxic frame (Kopf Instruments). Three unilateral infusions of $10 \mu \mathrm{g}$ of ibotenic acid, each in $4 \mu \mathrm{l}$ of phosphate-buffered saline $(\mathrm{pH}$ 7.4), were administered over a 4-min interval at the following coordinates: (1) $5 \mathrm{~mm}$ posterior to bregma, 2.5 $\mathrm{mm}$ lateral to the midline, and $4 \mathrm{~mm}$ below brain surface; (2) $5 \mathrm{~mm}$ posterior to bregma, $6.5 \mathrm{~mm}$ lateral to the midline, and $8 \mathrm{~mm}$ below the brain surface; (3) $7 \mathrm{~mm}$ posterior to bregma, $5 \mathrm{~mm}$ lateral to the midline, and 5 mm below brain surface. Following the lesions, the guinea pigs displayed generalized seizure activity which normally subsided within $24 \mathrm{hr}$. Intrahippocampal injections of ibotenate resulted in a $<20 \%$ death rate of guinea pigs. By contrast, kainic acid injections (three $1-\mu \mathrm{g}$ injections) were considerably more toxic and resulted in a mortality rate $>90 \%$. Twelve days after lesioning, guinea pigs were killed by either decapitation or stunning and exsanguination. In some animals, the brains were removed and frozen on dry ice, and 10 - to $20-\mu \mathrm{m}$ sections were thawmounted onto subbed microscope slides and stored at $-20^{\circ} \mathrm{C}$. For [ $\left.{ }^{:} \mathrm{H}\right] \mathrm{QNB}$ autoradiography, sections through various levels of the hippocampus were incubated for 3 $\mathrm{hr}$ in the presence of $1 \mathrm{nM}\left[{ }^{3} \mathrm{H}\right] \mathrm{QNB}$ (Wamsley et al., 1981). The slides were rinsed twice for $5 \mathrm{~min}$ in phosphate-buffered saline (pH 7.4) and air dried. Subsequently, contact autoradiograms were made by opposing the microscope slides to tritium-sensitive LKB Ultrofilm
(Penney et al., 1981) for 6 days. Selected sections also were stained with cresyl violet for histological examination.

Preparation of $P_{2} B$ nerve ending fractions from hippocampus and phospholipid labeling from ${ }^{32} P_{\mathrm{i}}$. The hippocampal formations (dentate gyrus and hippocampus proper) from two guinea pigs were dissected and divided into the control and lesioned sides. The tissues were homogenized in $5.5 \mathrm{ml}$ of $0.32 \mathrm{M}$ sucrose, an aliquot was retained for subsequent marker enzyme assay, and a nerve ending fraction $\left(P_{2} B\right)$ was prepared from the remainder by the method of Gray and Whittaker (1962). After removal of the $P_{2} B$ fraction from the hypertonic gradient, an excess of $0.17 \mathrm{M}$ sucrose was added to reduce the molarity of the sucrose to $0.4 \mathrm{~m}$. The $\mathrm{P}_{2} \mathrm{~B}$ fraction then was centrifuged at $105,000 \times g$ for $45 \mathrm{~min}$ and resuspended in $0.32 \mathrm{M}$ sucrose to yield protein concentrations of 1.25 to $2.5 \mathrm{mg} / \mathrm{ml}$. Lipid labeling at $37^{\circ} \mathrm{C}$ from ${ }^{32} \mathrm{P}_{\mathrm{i}}$ in the absence and presence of carbachol $(1 \mathrm{mM})$ was carried out by incubating aliquots of the $\mathrm{P}_{2} \mathrm{~B}$ fraction (130 to $270 \mu \mathrm{g}$ of protein) in a medium containing (final concentrations): $100 \mathrm{~mm}$ sodium glycylglycinate buffer (pH 7.4), $1 \mathrm{~mm}$ sodium pyruvate, $1 \mathrm{~mm}$ sodium fumarate, $1 \mathrm{~mm} \mathrm{MgSO}_{4}, 1 \mathrm{~mm}$ cytidine, $1 \mathrm{~mm}$ inositol, $0.1 \mathrm{~mm}$ $\mathrm{NaH}_{2} \mathrm{PO}_{4}$, and $50 \mu \mathrm{Ci}$ of ${ }^{32} \mathrm{P}_{\mathrm{i}}$ in a total volume of $0.25 \mathrm{ml}$. Incubations were terminated after 60 min and lipids were extracted and quantitated as previously described (Schacht et al., 1974) after the addition of carrier lipid from whole brain $(0.5 \mu \mathrm{mol}$ of lipid phosphorus). Under these assay conditions, the rate of incorporation of ${ }^{32} \mathrm{P}_{\mathrm{i}}$ into total phospholipids, PhA, and PhI was linear with the amount of protein in the range indicated. The percentage stimulation of $\mathrm{PhA}$ and $\mathrm{PhI}$ labeling by carbachol was independent of the protein concentration. Values for phospholipid labeling in the absence of added carbachol (i.e., basal labeling) are expressed as nanocuries of added ${ }^{32} \mathrm{P}_{\mathrm{i}}$ incorporated per $\mathrm{mg}$ of protein per $\mathrm{hr}$. The method used for calculation of the percentage stimulation or the reduction of labeling by cholinergic agonists was as previously described (Fisher and Agranoff, 1980).

Determination of marker enzymes. $\left[{ }^{3} \mathrm{H}\right] \mathrm{QNB}$ binding was measured as described previously (Yamamura and Snyder, 1974; Fisher et al., 1980), with the exception that the L (-) isomer of QNB was used. Choline acetyltransferase (ChAT) activity was measured by the method of Fonnum (1975). Glutamate decarboxylase (GAD) was measured as described previously (Fisher et al., 1980), with the exception that the final concentration of sodium L-glutamate was $20 \mathrm{~mm}$ and incubations were terminated after $60 \mathrm{~min}$. Protein was determined by the method of Geiger and Bessman (1972). Results are expressed as the mean \pm SEM. Student's $t$ tests were used to evaluate differences in the means of paired or unpaired sets of data.

\section{Results}

\section{Ibotenate lesions of the hippocampus: Histology and $\left[{ }^{3} H\right] Q N B$ autoradiography}

Intrahippocampal injections of ibotenate resulted in a marked loss of neuronal cell somata from both the hippocampus and dentate gyrus (Fig. 1A). Three 10- $\mu \mathrm{g}$ injections of ibotenate were required to ensure a wide- 

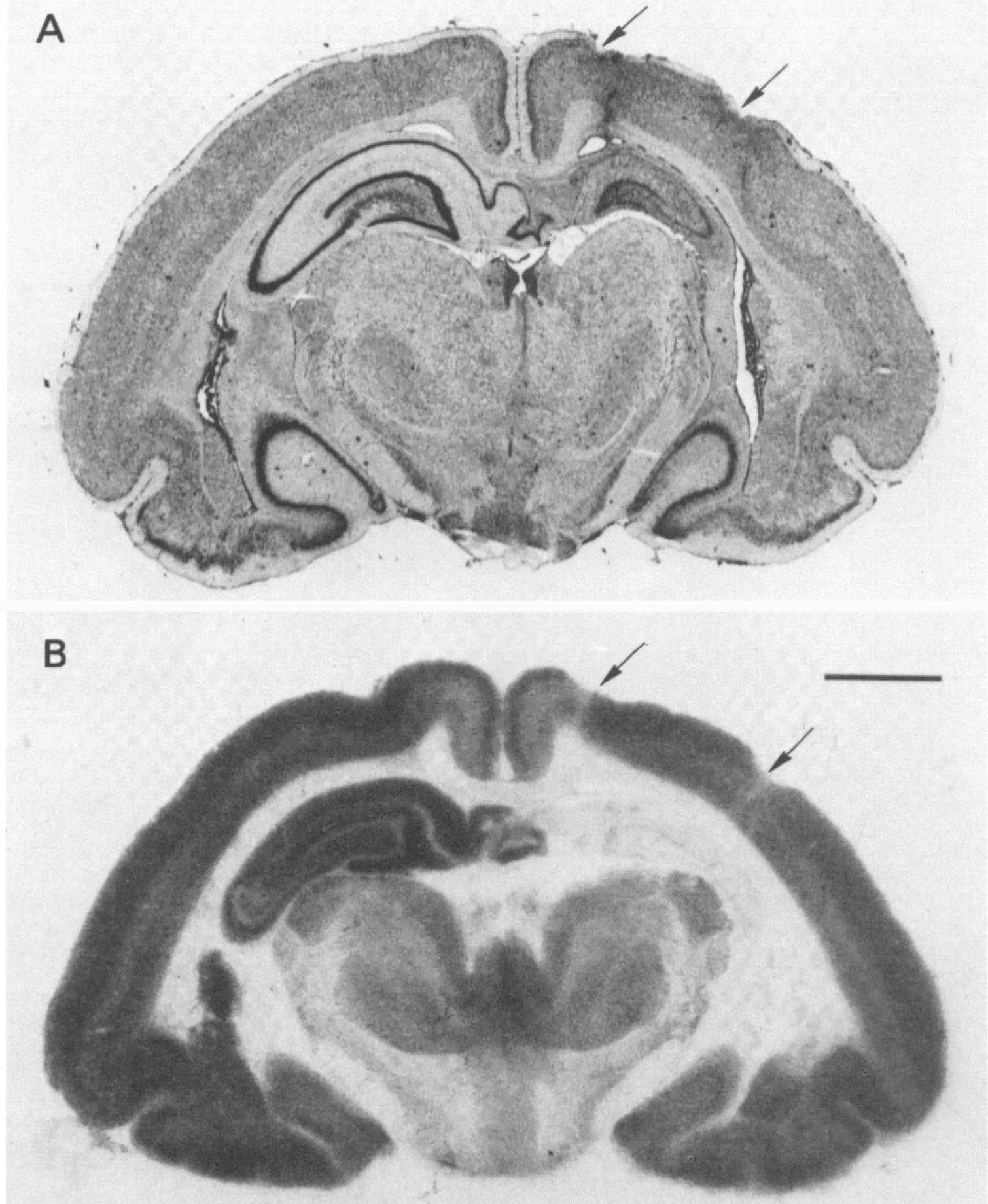

Figure 1. A, Coronal section of a guinea pig brain stained with cresyl violet illustrating the lesion in the right hippocampus. Note the loss of staining and atrophy of the lesioned dorsal hippocampus at this level. $B,\left[{ }^{3} \mathrm{H}\right] \mathrm{QNB}$ autoradiography of one of three animals, all of which demonstrated loss of muscarinic receptors in the lesioned hippocampus. The regional distribution of QNB binding on the control side demonstrates the highest concentration of muscarinic receptors in synaptic layers (stratum oriens and stratum radiatum of the hippocampus and stratum moleculare of the dentate gyrus) with relatively little binding over stratum pyramidale and dentate hilus. In addition to the stratification of receptor localization, there is considerable variation of binding along the circumferential axis of the hippocampus, with higher binding over stratum oriens in CA1 than in CA2 and CA3. Binding is not detectable in sections incubated in $\left[{ }^{3} \mathrm{H}\right] \mathrm{QNB}$ with the addition of $1 \mu \mathrm{M}$ atropine. Specificity of the lesion is demonstrated by the preservation of both morphology and receptor binding in structures adjacent to the hippocampal formation with the exception of the cannula tracts through the cerebral cortex (arrows). Bar $=3 \mathrm{~mm}$.

spread loss of intrinsic neurons throughout the entire hippocampus. No neuronal degeneration of structures adjacent to the lesioned hippocampus or on the control side was observed, the only exceptions being regions of the dorsal cerebral cortex through which the cannula was passed, which may reflect reflux of ibotenate along the cannula track. $\left[{ }^{3} \mathrm{H}\right] \mathrm{QNB}$ autoradiography revealed that the loss of cells on the lesioned side of the hippocampus 
was accompanied by a significant loss of muscarinic receptors (Fig. $1 B$ ).

\section{Ibotenate lesions of the hippocampus: Biochemical correlates}

Marker enzymes and $\left[{ }^{3} H\right] Q N B$ binding. The lesioned side of the hippocampus was shrunken in appearance and consistently weighed less than the hippocampus from the control side (Table I). In homogenates obtained from the lesioned hippocampus, the specific activity of GAD was reduced by $44 \pm 6 \%$, while $\left[{ }^{3} \mathrm{H}\right] \mathrm{QNB}$ binding was reduced by $53 \pm 4 \%$. Neither the activity of ChAT nor the concentration of protein per $\mathrm{mg}$, wet weight, were altered by the lesion (Table I). When nerve ending fractions $\left(\mathrm{P}_{2} \mathrm{~B}\right)$ were prepared from the two sides of the hippocampus, there was a notable reduction in the yield of protein per mg, wet weight, in the $\mathrm{P}_{2} \mathrm{~B}$ fraction from the lesioned side as compared to the control side $(25 \pm$ $4 \%$, Table I). In addition, both the specific activity of GAD and the binding of $\left[{ }^{3} \mathrm{H}\right] \mathrm{QNB}$ were reduced by $30 \%$ and $44 \%$, respectively, on the lesioned side. When the reduced yield of protein was taken into account, the calculated reduction of GABAergic synaptosomes on the lesioned side of the hippocampus was $48 \%$ and structures which possessed the muscarinic receptors were reduced by $58 \%$. The $\left[{ }^{3} \mathrm{H}\right] \mathrm{QNB}$ binding in $\mathrm{P}_{2} \mathrm{~B}$ fractions from unoperated, control animals was $1.30 \pm 0.04 \mathrm{pmol} / \mathrm{mg}$ of protein $(n=5)$, a value which was not statistically different from that obtained from the control side of lesioned animals. Scatchard analysis of $\left[{ }^{3} \mathrm{H}\right] \mathrm{QNB}$ binding from $\mathrm{P}_{2} \mathrm{~B}$ fractions prepared from the control and lesioned sides of the hippocampus revealed that, while the number of muscarinic receptors $\left(B_{\max }\right)$ was reduced, there was no significant alteration in the apparent affinity $\left(K_{d}\right)$ of the remaining muscarinic receptors for the ligand (12 to $25 \mathrm{pM}$ ). In contrast to the effect on GAD activity and $\left[{ }^{3} \mathrm{H}\right] \mathrm{QNB}$ binding, ChAT activity was unchanged or

TABLE I

Marker enzyme activities, $\left[{ }^{3} H\right] Q N B$ binding, and protein contents of homogenate and nerve ending fractions obtained from control and lesioned sides of the hippocampus

The numbers $(N)$ in the second column refer to the number of separate experiments performed, with each experiment utilizing the combined tissue from two animals. Units of measurement were as follows: ChAT and GAD, nanomoles per mg of protein per min; QNB, picomoles bound per $\mathrm{mg}$ of protein; protein, milligrams per gm, wet weight.

\begin{tabular}{cccc}
\hline & $N$ & Control & Lesion \\
\hline Hippocampus, wet weight $(\mathrm{mg})$ & 10 & $203 \pm 6$ & $171 \pm 10^{a}$
\end{tabular}

Homogenates

Protein

$\left[{ }^{3} \mathrm{H}\right] Q N B$

GAD

$\mathrm{ChAT}$

Nerve endings
Protein
$\left[{ }^{3} \mathrm{H}\right] \mathrm{QNB}$
GAD
ChAT

$114 \pm 4 \quad 110 \pm 4$ $0.74 \pm 0.01 \quad 0.35 \pm 0.03^{a}$ $2.70 \pm 0.15 \quad 1.55 \pm 0.22^{\circ}$

$8 \quad 0.80 \pm 0.03 \quad 0.84 \pm 0.02$
${ }^{a}$ Different from control side, $p<0.005$ (matched pair analysis). slightly increased in $\mathrm{P}_{2} \mathrm{~B}$ fractions derived from the lesioned hippocampus, thus confirming the observation of Schwarcz et al. (1979) that cholinergic nerve terminals are spared the lesion (Table I).

Phospholipid labeling from ${ }^{32} P_{\mathrm{i}}$. More than $90 \%$ of the ${ }^{32} \mathrm{P}_{\mathrm{i}}$ incorporated into phospholipids in $\mathrm{P}_{2} \mathrm{~B}$ fractions from both the control and lesioned hippocampus was recovered in four phospholipids, $\mathrm{PhA}$ and $\mathrm{PhI}$ and the polyphosphoinositides, phosphatidylinositol phosphate and phosphatidylinositol diphosphate. There was little or no label associated with the quantitatively major phospholipids, such as phosphatidylcholine or phosphatidylethanolamine. Only the labeling of $\mathrm{PhA}$ and $\mathrm{PhI}$ was stimulated by the addition of $1 \mathrm{~mm}$ carbachol, while the labeling of the polyphosphoinositides (which accounted for more than $70 \%$ of basal ${ }^{32} \mathrm{P}_{\mathrm{i}}$ incorporation into phospholipids) was reduced by 10 to $20 \%$. Although the alterations in polyphosphoinositide labeling in response to carbachol are specific receptor-mediated events (Fisher and Agranoff, 1981), the magnitude of the effect was small in comparison to the changes in $\mathrm{PhA}$ and $\mathrm{PhI}$ labeling, and thus, only the latter were measured routinely in the present study.

In addition to carbachol, three other muscarinic agonists, acetylcholine, muscarine, and methacholine, also produced a significant stimulation of $\mathrm{PhA}$ labeling (50 to $80 \%, p<0.01$ ) and of PhI labeling (27 to $30 \%, p<0.01$ ) at concentrations of $10^{-4}$ to $10^{-3} \mathrm{M}$. The addition of oxotremorine, bethanechol, pilocarpine, or arecoline resulted in little or no stimulation of PhA labeling $(<20 \%)$ and no stimulation of $\mathrm{PhI}$ labeling, as previously observed for the cerebral cortex (Fisher and Agranoff, 1981). Blockage of the muscarinic receptors by the addition of $10^{-8} \mathrm{M}$ unlabeled QNB completely prevented the carbachol-induced stimulation of $\mathrm{PhA}$ and $\mathrm{PhI}$ labeling, while a concentration of $10^{-4} \mathrm{M} d$-tubocurarine was without effect on either basal or stimulated phospholipid labeling. The total basal (unstimulated) incorporation of ${ }^{32} \mathrm{P}_{\mathrm{i}}$ into phospholipids in the $\mathrm{P}_{2} \mathrm{~B}$ fraction from the lesioned hippocampus was reduced by $41 \pm 6 \%(n=8)$ as compared to the control $\mathrm{P}_{2} \mathrm{~B}$ fraction, presumably due to the loss of neuronal rather than non-neuronal structures. When the specific activities of ${ }^{32} \mathrm{P}_{\mathrm{i}}$ incorporation into total phospholipids and into $\mathrm{PhA}$ and $\mathrm{PhI}$ (computed per milligram of protein) were compared from the two sides, the values were comparable (Fig. $2 A$ ), although there was a small increase in the basal labeling of $\mathrm{PhA}$ on the lesioned side. Thus, although the nerve ending fraction yield is reduced following an ibotenate lesion, the neuronal structures in the $\mathrm{P}_{2} \mathrm{~B}$ fraction in which lipid phosphorylation occurs do not show an impaired ability to incorporate ${ }^{32} \mathrm{P}_{\mathrm{i}}$ into their phospholipids. There was, however, a marked impairment of the ability of carbachol to stimulate the labeling of $\mathrm{PhA}$ and PhI. The mean stimulations of PhA labcling in the control and lesioned hippocampus in response to carbachol addition were thus $91 \pm 9 \%$ and $52 \pm 7 \%$, respectively, while the corresponding values for $\mathrm{PhI}$ stimulation were $31 \pm 5 \%$ and $19 \pm 4 \%$ (Fig. 2B). Carbachol-stimulated $\mathrm{PhA}$ and $\mathrm{PhI}$ labeling in $\mathrm{P}_{2} \mathrm{~B}$ fractions obtained from unoperated animals were 98 $\pm 19 \%$ and $28 \pm 4 \%$, respectively $(n=4)$, values obtained from lesioned animals. 


\section{A. BASAL PHOSPHOLIPID LABELING}
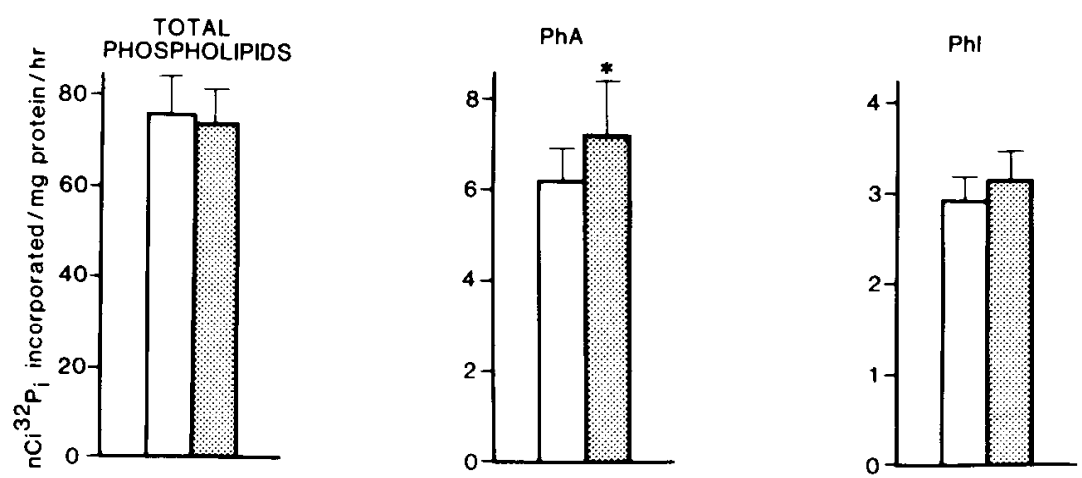

\section{B. CARBACHOL-STIMULATED LABELING}
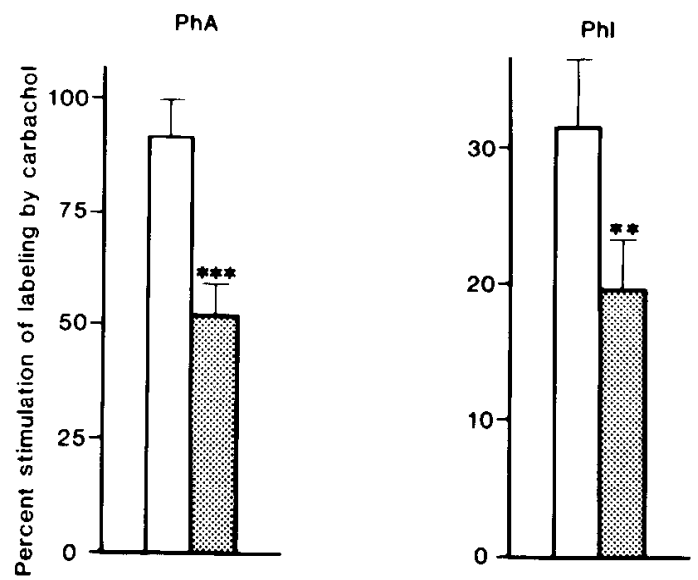

Figure 2. A, Lipid phosphorylation from ${ }^{32} \mathrm{P}_{\mathrm{i}}$ (in the absence of added carbachol) in nerve ending fractions derived from control (open bar) and lesioned (hatched bar) sides of the hippocampus. $B$, Carbachol-stimulated labeling of $\mathrm{PhA}$ and $\mathrm{PhI}$ from ${ }^{32} \mathrm{P}_{\mathrm{i}}$ in nerve ending fractions derived from control (open bar) and lesioned (hatched bar) sides of the hippocampus. The results, expressed as the mean \pm SEM are from eight separate experiments, with each experiment utilizing the combined tissue from two animals. Different from control side, ${ }^{*} p=0.05 ;{ }^{* *} p<0.02 ;{ }^{* * *} p<0.005$ (matched pair analysis).

\section{Discussion}

In this study, the use of the neurotoxin, ibotenic acid, has provided direct autoradiographic and biochemical evidence that muscarinic receptors in the hippocampus are located predominantly on intrinsic neurons within this structure. The homogenate binding data do not demonstrate as complete a loss of $\left[{ }^{3} \mathrm{H}\right] \mathrm{QNB}$ binding as do the autoradiograms, since the latter were taken through one of the three injection sites, while hippocampal dissection for binding studies included some nonlesioned tissue. In any event, the observation that the reduction in the numbers of muscarinic receptors in the nerve ending fraction is accompanied by a parallel reduction in the magnitude of muscarinic-agonist stimulation of $\mathrm{PhA}$ and $\mathrm{PhI}$ labeling strongly suggests that ibotenate selectively destroys those structures which possess the muscarinic receptors that mediate stimulated phospholipid turnover.

The inferred location of muscarinic receptors in the hippocampus has been a subject of recent controversy. Previous studies employing radiolabeled agonists and antagonists have failed to obtain evidence for the existence of presynaptic muscarinic receptors in the rat hippocampus following lesions of the cholinergic input (Yamamura and Snyder, 1974; Dudai and Segal, 1978; Overstreet et al., 1980; Kamiya et al., 1981). On the other hand, the presence of muscarinic autoreceptors in the hippocampus has been suggested from both neurophysiological (Hounsgaard, 1978) and biochemical criteria (Szerb et al., 1977; Nordstrum and Bartfai, 1980). While the existence of a small population of muscarinic autoreceptors cannot be excluded, it is clear from both the present and a previous study (Fisher et al., 1980) that their contribution to either the total number of receptors present or to those receptors coupled to stimulated phospholipid turnover in the hippocampus is minimal.

Muscarinic receptors have been identified on both cholinergic and non-cholinergic nerve endings in the peripheral and central nervous system where they are envisaged to play a modulatory role in neurotransmitter release at cholinergic, noradrenergic, serotonergic, and dopaminergic nerve endings (Szerb and Somogyi, 1973; Giorguieff et al., 1977; Hery et al., 1977; deBelleroche and 
Bradford, 1978; Ganguly and Das, 1979). However, the previous demonstrations of an extrinsic origin for cholinergic, noradrenergic, and serotonergic fiber tracts in the hippocampus (Lewis et al., 1967; Storm-Mathisen and Guldberg, 1974; Schwarcz et al., 1979) and the localization of muscarinic receptors to intrinsic neurons in the present study imply that muscarinic receptors are not present to a significant extent on nerve endings derived from these tracts. Thus, although intrinsic in origin, the precise cellular origin of the muscarinic receptors remains uncertain. There is evidence for the existence of GABAergic, glutamatergic, and aspartergic neurons intrinsic to the hippocampus (Fonnum and Walaas, 1978), and while muscarinic receptors have not as yet been identified on nerve endings derived from these neurons, this possibility remains. In a previous autoradiographic study (Kuhar and Yamamura, 1976), it was observed that the muscarinic receptors in the hippocampus appeared to be particularly concentrated over dendritic fields. This raises the possibility, as yet unproven, that, in the hippocampus, dendrites may break off during homogenization to form "dendrosomes," and it is these structures rather than synaptosomes that are responsible for the presence of the muscarinic receptors in nerve ending fractions that are coupled to phospholipid turnover. In this context, it should be noted that dendrites from the substantia nigra break off during homogenization and form resealed structures similar to light synaptosomes in their behavior on density gradient centrifugation (Hefti and Lichtensteiger, 1978).

The characteristics of stimulated phospholipid labeling in the hippocampus appear identical to those observed previously in the cerebral cortex, which would suggest a similar location and function for stimulated labeling in both brain areas. Thus, both tissues demonstrate a similar profile of efficacy of various muscarinic agonists in eliciting a selective stimulation of $\mathrm{PhA}$ and $\mathrm{PhI}$ labeling in synaptosomes (Fisher and Agranoff, 1980, 1981). In addition, the presence of micromolar concentrations of calcium appear to be required for stimulated labeling since EGTA (ethylene glycol bis ( $\beta$-aminoethyl ether)$N, N, N^{\prime}, N^{\prime}$-tetra-acetic acid) addition $(0.5 \mathrm{~mm})$ abolishes stimulated phospholipid labeling in the hippocampus (results not shown) as it does in the cerebral cortex (Griffin et al., 1979; Fisher and Agranoff, 1980). The observation that the stimulation of $\mathrm{PhA}$ and $\mathrm{PhI}$ turnover in nerve ending fractions is a function of the activation of a receptor at a postsynaptic locus is in agreement with the inferred localization of stimulated phospholipid labeling in both the pineal gland (Smith et al., 1979) and the superior cervical ganglion (Larrabee and Leicht, 1965; Hokin, 1966; Larrabee, 1968).

\section{References}

Birdsall, N. J. M., and E. C. Hulme (1976) Biochemical studies on muscarinic acetylcholine receptors. J. Neurochem. 27: 716.

Canessa de Scarnati, O., M. Sato, and E. DeRobertis (1976) Muscarinic receptors and the ACh stimulated phosphatidylinositol effect in the CNS. J. Neurochem. 27: 1575-1577.

deBelleroche, J., and H. F. Bradford (1978) Biochemical evidence for the presence of presynaptic receptors on dopaninergic nerve terminals. Brain Res. 142: 53-68.
Dudai, Y., and M. Segal (1978) $\alpha$-Bungarotoxin binding sites in rat hippocampus: Localization in postsynaptic cells. Brain Res. 154: 167-171.

Ehlert, F. J., W. R. Roeske, and H. I. Yamamura (1981) Muscarinic receptor: Regulation of guanine nucleotides, ions and $N$-ethylmaleimide. Fed. Proc. 40: 153-159.

Fisher, S. K., and B. W. Agranoff (1980) Calcium and the muscarinic synaptosomal phospholipid labeling effect. J. Neurochem. 34: 1231-1240.

Fisher, S. K., and B. W. Agranoff (1981) Enhancement of the muscarinic synaptosomal phospholipid labeling effect by the ionophore A23187. J. Neurochem. 37: 968-977.

Fisher, S. K., C. A. Boast, and B. W. Agranoff (1980) The muscarinic stimulation of phospholipid labeling in hippocampus is independent of its cholinergic input. Brain Res. 189: 284-288.

Fonnum, F. (1975) A rapid radiochemical method for the determination of choline acetyltransferase. J. Neurochem. 24: 407-409.

Fonnum, F., and I. Walaas (1978) The effect of intrahippocampal kainic acid injections and surgical lesions on neurotransmitters in hippocampus and septum. J. Neurochem. 31: 11731181.

Ganguly, D. K., and M. Das (1979) Effects of oxotremorine demonstrate presynaptic muscarinic and dopaminergic receptors on motor nerve terminals. Nature 278: 645-646.

Geiger, P. J., and S. P. Bessman (1972) Protein determination by Lowry's method in the presence of sulphydryl reagents. Anal. Biochem. 49: 467-473.

Giorguieff, M. F., M. L. Le Floc'h, J. Glowinski, and M. J. Besson (1977) Involvement of cholinergic presynaptic receptors of nicotinic and muscarinic types in the control of the spontaneous release of dopamine from striatal dopaminergic terminals in the rat. J. Pharmacol. Exp. Ther. 200: 535-544.

Gray, E. G., and V. P. Whittaker (1962) The isolation of nerve endings from brain: An electronmicroscopic study of cell fragments derived by homogenization and centrifugation. $J$. Anat. 96: 79-88

Griffin, H. D., J. N. Hawthorne, M. Sykes, and A. Orlacchio (1979) A calcium requirement for the phosphatidylinositol response following activation of presynaptic muscarinic receptors. Biochem. Pharmacol. 28: 1143-1147.

Hawthorne, J. N., and M. R. Pickard (1979) Phospholipids in synaptic function. J. Neurochem. 32: 5-14.

Hefti, F., and W. Lichtensteiger (1978) Subcellular distribution of dopamine in substantia nigra of rat brain: Effects of $\alpha$ butyrolactone and destruction of noradrenergic afferents sug. gest formation of particles from dendrites. J. Neurochem. 30: 1217-1230.

Hery, F., S. Bourgoin, M. Hamon, J. Ternaux, and J. Glowinski (1977) The role of nicotinic and muscarinic receptors in the control of the release of newly synthesized ${ }^{3} \mathrm{H}-5-\mathrm{HT}$ in rat hypothalamic slices. Naunyn Schmeidebergs Arch. Pharmacol. 296: 91-97.

Hokin, L. E. (1966) Effects of acetylcholine on the incorporation of ${ }^{32} \mathrm{P}$ into various phospholipids in slices of normal and denervated superior cervical ganglia of the cat. J. Neurochem. 13: 179-184.

Hokin, L. E., and M. R. Hokin (1955) Effects of acetylcholine on the turnover of phosphoryl units in individual phospholipids of pancreas slices and brain cortex slices. Biochim. Biophys. Acta 18: 102-110.

Hounsgaard, J. (1978) Presynaptic inhibitory action of acetylcholine in area CA1 of the hippocampus. Exp. Neurol. 62: 787-797

Kamiya, H. O., A. Rotter, and D. M. Jacobowitz (1981) Muscarinic receptor binding following cholinergic nerve lesions of the cingulate cortex and hippocampus of the rat. Brain Res. 209: 432-439. 
Kohler, C., R. Schwarcz, and K. Fuxe (1979) Intrahippocampal injections of ibotenic acid provide histological evidence for a neurotoxic mechanism different from kainic acid. Neurosci. Lett. 15: 223-228.

Kuhar, M. J., and H. I. Yamamura (1976) Localization of cholinergic muscarinic receptors in rat brain by light microscopic radioautography. Brain Res. 110: 229-243.

Lapetina, E. G., W. E. Brown, and R. H. Michell (1976) Muscarinic cholinergic stimulation of phosphatidylinositol turnover in isolated rat superior cervical sympathetic ganglia. J. Neurochem. 26: 649-651.

Larrabee, M. G. (1968) Transynaptic stimulation of phosphatidylinositol metabolism in sympathetic neurons in situ. J. Neurochem. 15: 803-808.

Larrabee, M. G., and W. S. Leicht (1965) Metabolism of phosphatidylinositol and other lipids in active neurones of sympathetic ganglia and other peripheral nervous tissues. The site of the inositide effect. J. Neurochem. 12: 1-13.

Lewis, P. R., C. C. D. Shute, and A. Silver (1967) Confirmation from choline acetylase of a massive cholinergic innervation to the rat hippocampus. J. Physiol. (Lond.) 191: 215-224.

Nordstrom, O., and T. Bartfai (1980) Muscarinic autoreceptors regulate acetylcholine release in rat hippocampus: In vitro evidence. Acta Physiol. Scand. 108: 347-353.

Overstreet, D. H., R. C. Speth, R. E. Hruska, F. Ehlert, Y. Dumont, and H. I. Yamamura (1980) Failure of septal lesions to alter muscarinic cholinergic or benzodiazepine binding sites in hippocampus of rat brain. Brain Res. 195: 203-207.

Penney, J. B., K. A. Frey, and A. B. Young (1981) Quantitative autoradiography of neurotransmitter receptors using tritium sensitive film. Eur. J. Pharmacol. 72: 421-422.

Reddy, P. V., and P. S. Sastry (1979) Studies on neurotransmitter-stimulated phospholipid metabolism with cerebral tissue suspensions: A possible biochemical correlate of synaptogenesis in normal and undernourished rats. Brain Res. 168: 287-298.

Schacht, J., and B. W. Agranoff (1972) Effect of acetylcholine on labeling of phosphatidate and phosphoinositides by ${ }^{32} \mathrm{P}$ orthophosphate in nerve ending fractions of guinea-pig cortex. J. Biol. Chem. 247: 771-777.

Schacht, J., E. A. Neale, and B. W. Agranoff (1974) Cholinergic stimulation of phospholipid labelling from $\left[{ }^{32} \mathrm{P}\right]$ orthophosphate in guinea pig cortex synaptosomes in vitro: Subsynaptosomal localization. J. Neurochem. 23: 211-218.

Schwarcz, R., T. Hokfelt, K. Fuxe, G. Jonsson, M. Goldstein, and $\mathrm{L}$. Terenius (1979) Ibotenic acid-induced neuronal degeneration: A morphological and neurochemical study. Exp. Brain Res. 37: 199-216.

Smith, T. L., J. Eichberg, and G. Hauser (1979) Postsynaptic localization of the alpha receptor-mediated stimulation of phosphatidylinositol turnover in pineal gland. Iife Sci. 24: 2179-2184.

Storm-Mathisen, J., and H. C. Guldberg (1974) 5-Hydroxytryptamine and noradrenaline in the hippocampal region: Effects of transection of afferent pathways, on endogenous levels, high affinity uptake and some transmitter related enzymes. J. Neurochem. 22: 793-803.

Szerb, J. C., and G. T. Somogyi (1973) Depression of acetylcholine release from cortical slices by cholinesterase inhibition and by oxotremorine. Nature New Biol. 241: 121-122.

Szerb, J. C., P. Hadhazy, and J. D. Dudar (1977) Release of $\left[{ }^{3} \mathrm{H}\right]$ acetylcholine from rat hippocampal slices: Effect of septal lesion and of graded concentrations of muscarinic agonists and antagonists. Brain Res. 128: 285-291.

Wamsley, J. K., M. S. Lewis, W. S. Young, III, and M. J. Kuhar (1981) Autoradiographic localization of muscarinic cholinergic receptors in rat brainstem. J. Neurosci. 1: 176-191.

Yagihara, Y., and J. N. Hawthorne (1972) Effects of acetylcholine on the incorporation of ${ }^{32} \mathrm{P}_{\mathrm{i}}$ in vitro into phospholipids of nerve ending particles from guinea pig brain. J. Neurochem. 19: 355-367.

Yamamura, H. I., and S. Snyder (1974) Postsynaptic localization of muscarinic cholinergic receptor binding in rat hippocampus. Brain Res. 78: 320-326. 